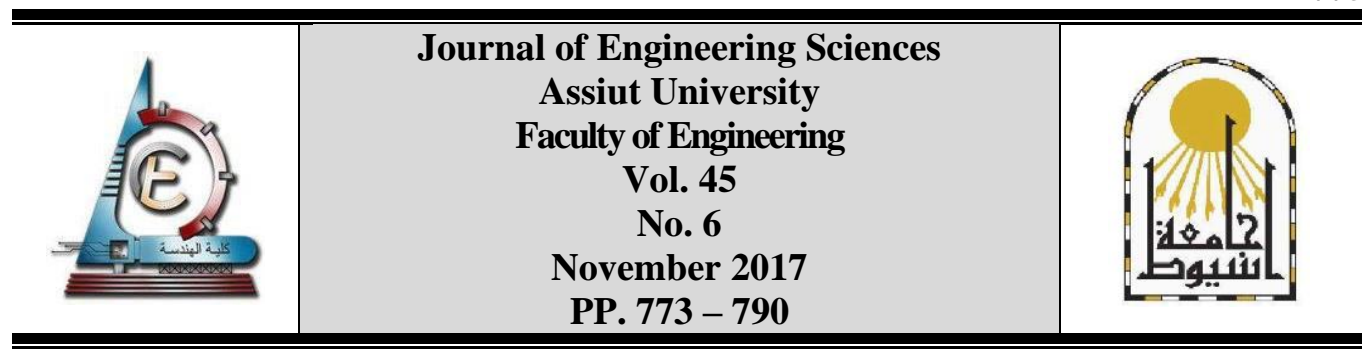

\title{
EFFICIENT RISK MANAGEMENT: CAUSE AND EFFECT ANALYSIS OF KEY RISKS OF COMPLEX CONSTRUCTION PROJECTS IN EGYPT
}

\author{
Khodeir, Laila Mohamed \\ Architecture, Ain Shams University, Cairo, Egypt \\ Received 5 September 2017; Accepted 8 October 2017
}

\begin{abstract}
Complex construction Projects represent time-consuming projects that have complexity in structural systems, building control systems or in their architectural design. In general, the objective of risk management is to predict, reduce and avoid the risks and their consequences. The primary objective of this research is to undergo a cause-and-effect analysis of the key risks that face complex construction projects, thus enhancing their project delivery success. The methodology used is an integrative review of the existing literature on the key concepts including risk management of complex construction projects .In addition, qualitative analysis of the case study of the Grand Egyptian Museum, as one of the pioneering complex projects, has been performed to analyze key causes of risk in this type of projects. The study covers the period from 2014 to 2016, as the project is still in progress. Finally, a survey targeting stakeholders involved in the construction and management of complex construction projects was conducted. The study findings shed light on the key causes and effects of risks affecting the success of complex projects and their effect on different project constraints. The study results showed that root causes of risks are mainly related to managerial complexities in the project. These complexities are namely: lack of proper management and uncertainties in management goals and methods. Technical complexities, however, have the most severe impact on the risks affecting complex constructions. The top identified risk was found to be improper planning, followed by legislative risk, and scope changes. These results make it clear that managerial complexities are of the same importance as technical complexities. Thus, this study underscores the role played by efficient management in managing risks and in enhancing the success of complex construction projects delivery process
\end{abstract}

Keywords: Complex Construction Projects (CCPs); Risk Management (RM); Root Cause Analysis (RCA); Grand Egyptian Museum (GEM); Egypt.

\section{Introduction}

In general, planning a construction project is the most important pillar of a successful project delivery. However, even with a well-planned strategy, errors and failures will arise. One of the most dangerous aspects in a project is the unpredictability and uncertainty of the project's environment. Risks are found in all phases and activities of construction projects. These risks are either derived from external or internal sources, where external risks normally represent environmental-related risks, while internal risks exist in the 
project itself. Risk in the architecture, engineering and construction (AEC) industry is mainly caused due to "the lack of familiarity of project management standards" [1]. Influential environments can differ from unsuccessful delivery of design plans (design phase) to a sudden crash in market liquidity (construction phase) of some parts involved in the project. Here comes the role of Risk management, which is defined as a systematic way of identifying, analyzing and dealing with risks associated with a project, with the aim of achieving the project objectives [2]. However, these risks are more evident in the complex Construction Projects, which incur more uncertainties. This owes to their large size and the international involvement of different stakeholders [3].

Similar to its worldwide counterparts, the AEC industry in Egypt is one of the main sources of economy in the country [4]. Complex construction projects have increased over the past few years, starting with joint ventures with Arabian Gulf countries, Japanese infrastructure collaboration and Scandinavian countries partnership projects. This imposes risks, such as differences in practices between domestic and foreign partners, policy and financial risks and legal and political risks. Among the factors that caused a high source of external risk during the years 2011 to 2013 were "currency fluctuation, change in taxation rates, change in energy cost and unsecured roads" [4]. A number of these factors were caused by the changing political situation due to the events of the $25^{\text {th }}$ of January Revolution. However, causes of internal risk that included "bad communication between stakeholders, poor documentation and poor project planning" were not triggered nor affected by the revolution. In order to minimize these impacts, risk management is an important aspect to consider in construction project management. Thus, the primary objective of this research is to undergo a cause/effect analysis of the key risks that face complex construction projects, thus enhancing their project delivery success.

\section{Literature review}

The literature review in this paper starts with discussing the definitions of construction projects complexities and how construction projects were proven to be complex in nature. In addition, types of complexities are also discussed. Afterwards, the literature discusses and explains the risk management process and how it was defined, explained and analyzed through extant literature. Finally, the limitations of risk management in AEC Industry are discussed.

\subsection{Complexities in construction projects}

According to The Collins English Dictionary, 2006, complexity is defined as "the state or quality of being intricate or complex", where complex is defined as "made up of many interconnecting parts" [5]. When applying this definition on construction projects, almost all of them can be described as "Complex". Table 1 summarizes different definitions and descriptions of complex projects through literature. However, complex construction buildings can be identified among other types of buildings according to two main dimensions: structural complexity and uncertainty. Figure 1 shows that structural complexity depends on number of project elements and independence of elements. Uncertainty in goals and methods is another dimension which makes the project complex [6].

For the purpose of this research, project complexity has been defined as factors that affect the actions taken to achieve the project objectives. Complexities are thus classified into two groups. The first is managerial complexities, either in uncertainty in goals or uncertainty of methods, or lack of application of proper management. The second, 
technical complexities, is subdivided into scope complexity, design complexity, structural complexity, and maintenance and operation complexity, Figure 2.
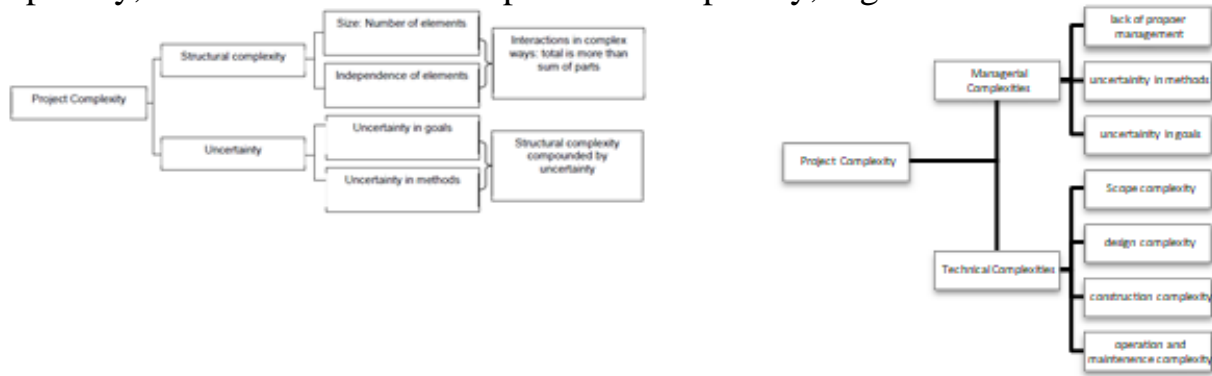

Fig. 1. Dimensions of Project Complexity [6]

Fig. 2. The clas sification of construction projects complexities, Author after extant literature.

Table 1.

Construction project complexity

\begin{tabular}{|c|c|c|}
\hline Author & Major findings & Contribution \\
\hline $\begin{array}{l}\text { Baccarini (1996) } \\
\text { [7], Mills (2001) } \\
\text { [8] Mulholland } \\
\text { and Christian } \\
(1999) \text { [9] }\end{array}$ & $\begin{array}{l}\text { - construction is the most complex } \\
\text { undertaking in any industry } \\
\text { - the industry has a very poor reputation } \\
\text { for managing risk } \\
\text { - construction projects are initiated } \\
\text { in complex and dynamic environments }\end{array}$ & $\begin{array}{l}\text { Proved that construction industry } \\
\text { is complex, and that it lacks } \\
\text { efficient risk management. }\end{array}$ \\
\hline Baccarini (1996) [7] & $\begin{array}{l}\text { Complexity of construction projects lies } \\
\text { in their many varied interrelated parts. } \\
\text { Complexities can be operationalized in } \\
\text { terms of variation and interdependence } \\
\text { Complexity affects the project } \\
\text { objectives of time, cost and quality. }\end{array}$ & $\begin{array}{l}\text { Offered a definition that can be } \\
\text { applied to any project dimension. } \\
\text { Highlighted the importance of } \\
\text { determining the type of project } \\
\text { complexity. } \\
\text { Highlighted the importance of } \\
\text { complexity to the project } \\
\text { management process }\end{array}$ \\
\hline Gidado (1996) [10] & $\begin{array}{l}\text { - complexity is the measure of difficulty of } \\
\text { executing a complex production process } \\
\text { - Determination of two main perspectives: } \\
\text { managerial perspective (planning of } \\
\text { bringing together numerous parts of } \\
\text { work to form work flow) and the } \\
\text { operative and technological perspective } \\
\text { (difficulties of executing individual } \\
\text { pieces of work). }\end{array}$ & $\begin{array}{l}\text { Defined complexities and started } \\
\text { to categorize their types. }\end{array}$ \\
\hline Bertelsen (2003) [11] & $\begin{array}{l}\text { discusses construction as a complex } \\
\text { system }\end{array}$ & $\begin{array}{l}\text { Redefined the construction } \\
\text { process as a non-linear, complex } \\
\text { and dynamic phenomenon. }\end{array}$ \\
\hline
\end{tabular}

\subsection{Introduction to risk management}

The previous part of this paper made it clear that construction projects are complex projects that have several types of complexities. In addition most researchers agreed that such complex projects lack efficient application of risk management. The coming part of this paper will concentrate more on risk management process and how it was discussed through extant literature. Till 2009, only few attempts have been made on the identification and 
assessment of risk factors of the construction projects. As a result, there was a lack of systematic approaches to identify and manage the risks in construction projects. However, a number of attempts have been made to identify risks: table 2 summarizes these attempts. In the past 2000's many researchers attempted to propose limitations and complexity of risk assessment tools, such as analytical hierarchy process (AHP) and decision support system.

Table 2.

Contributions of researchers to risk identification

\begin{tabular}{|c|c|}
\hline Author & Contribution to risk identification \\
\hline $\begin{array}{l}\text { Chapman R.J., } \\
(2001)[12]\end{array}$ & Grouped risks into four subsets: environment, industry, client and project \\
\hline $\begin{array}{l}\text { (Shen, 2001) } \\
{[13]}\end{array}$ & $\begin{array}{l}\text { Grouped risks into six groups according to the nature of the risks: financial, } \\
\text { legal, management, market, policy, and political. }\end{array}$ \\
\hline $\begin{array}{l}\text { (Chen et al, } \\
2004)[14]\end{array}$ & $\begin{array}{l}\text { Proposed } 15 \text { risks affecting project cost, under three heads: resource factors, } \\
\text { management factors and parent factors }\end{array}$ \\
\hline $\begin{array}{l}\text { (Dikmen et al, } \\
2007[15]\end{array}$ & Used influence diagrams to define the factors which have influence on project cost \\
\hline $\begin{array}{lrr}\text { Zeng et al, } \\
2007)[16]\end{array}$ & s human, site, material and $e$ \\
\hline $\begin{array}{l}\text { Matineh } \\
\text { Eybpoosh, Irem } \\
\text { (2011) [17] }\end{array}$ & $\begin{array}{l}\text { Classified risk factors under three heads: External, Legal and internal. External } \\
\text { risk was sub-divided into two subsets: unpredictable/uncontrollable, } \\
\text { predictable/uncontrollable; and Internal risk was sub-divided into two subsets: } \\
\text { Non- technical / controllable, Technical / controllable. }\end{array}$ \\
\hline
\end{tabular}

There are different types of risk classification. Risk can be classified according to its outcome, [18]. Positive risks are risks that have a positive outcome; they are considered opportunities. Negative risks, on the other hand, are risks that have a negative outcome, and they are considered threats. Classification can occur according to possibility of reduction where risk is split into two categories: diversifiable and non-diversifiable risks. Diversifiable risks are risks that can be eliminated by diversification. Non-diversifiable risks, however, cannot be completely eliminated despite attempts of Ben-Horim \& Levy, 1980; Peirson et al., 2011 [19], [20]. A project manager can control internal risks as they arise from within an organization, while external risks cannot be controlled as they are out of the project manager's reach. The possibility of risk occurrence is split into two categories: pure and speculative risk [18]. Pure risks are known to have either a negative or neutral impact. Speculative risks can have a positive, negative or neutral impact.

The RM process is the process by which RM is applied. It is done through four main steps: (a) risk identification, (b) risk analysis, (c) risk response development and (d) risk response control [21], [22]. The first step in the process of risk identification is the risk realization in the building process. The next step is the classification of key factors, where root causes of risk are classified. Data concerning the risk identification must be gathered from documentations, expertise or feedback. Identifying risks could be performed by brainstorming sessions, meetings or external notifications, [23]. The most widely used and most reliable risk identification tools include using the Delphi technique Interviewing, Root cause analysis, Checklist analysis, diagramming techniques and the SWOT analysis. Identification of risks occurs more than once in a project. It is not restricted to the start of the project; it can be done through checklists, flowcharting and interviewing [21]. 
The third step in the risk management process is risk response development, which depends on the type of risk. If the risk is considered a threat, actions taken to respond are avoidance, mitigation, transfer and acceptance. In the case that a risk is considered an opportunity, response actions include enhancement, exploitation and acceptance. The last step of the RM process is risk response control. It is considered the implementation of the plans created at the earlier steps of the process. If the risk that occurs is not foreseen beforehand, repetition of risk response strategies should take place, as the suggested solution might prove to be inadequate.

\subsection{Limitations of risk management in the AEC industry}

In this last part of the literature review, the reasons beyond the inconsistency in the RM application in the construction industry are investigated. One of the causes of this is that "the focus is almost entirely tactical and does not consider strategic sources of risk which might affect either the project or the wider business". Tactics are carefully planned to reach a certain end. Strategies, however, are concerned with long-term aims. This affects the application of RM as the focus becomes aimed at "meeting the deliverables" only, leading to missing out on several opportunities [22]. Another cause of defect in RM application in construction is that "formal risk analysis and management techniques are rarely used due to a lack of knowledge and to doubts on the suitability of these techniques for construction industry activities" [24]. As a result, RM in the AEC industry usually depends on experience and intuition [25]. Although they have proven to be valuable assets of RM, experience and intuition cannot be considered as formal approaches, [26], [27]. They merely serve as supplementary additions to enhance existing RM techniques. In Egypt, two recent studies Khodeir 1., et al., 2015 and Sharaf \& Abdelwahab , 2015 [4], [1] discussed the limitations facing risk management in AEC industry. The former study stated that currency fluctuation, change in taxation rate, changes in energy costs and security issues are among the major external limitation to applying efficient risk management, whereas the internal limitations were poor stakeholders' communication, poor documentation and poor project planning. The later study highlighted the limitation of lack of familiarity with project management standards. Table 3 summarizes the main topics that were analyzed and discussed in literature review.

Table 3.

Summary of the main topics of the literature review

\begin{tabular}{|c|c|c|c|c|c|}
\hline Authors & $\begin{array}{c}\text { Major } \\
\text { Findings }\end{array}$ & & & & \\
\hline & $\begin{array}{c}\text { RM } \\
\text { Definition } \\
\text { (RM is } \\
\text { about } \\
\text { anticipation } \\
\text { and } \\
\text { prevention) }\end{array}$ & $\begin{array}{c}\text { Classification of } \\
\text { Types of Risk } \\
\text { (Positive/negative, } \\
\text { Internal External, } \\
\text { Pure /Speculative, } \\
\text { Natural/human) }\end{array}$ & $\begin{array}{c}\text { Defining RM } \\
\text { process } \\
\text { (Identification, } \\
\text { analysis, } \\
\text { response } \\
\text { development, } \\
\text { control) }\end{array}$ & $\begin{array}{c}\text { RM } \\
\text { limitations } \\
\text { Worldwide }\end{array}$ & $\begin{array}{c}\mathrm{RM} \\
\text { limitations } \\
\text { in Egypt }\end{array}$ \\
\hline Duncan ,1996 & $*$ & & $*$ & & \\
\hline Ehsan etal, 2010 & $*$ & & & & \\
\hline Hillson, 1999 & $*$ & & & & \\
\hline $\begin{array}{l}\text { Banaitiene \& } \\
\text { Banaitis, 2012 }\end{array}$ & & $*$ & & & \\
\hline
\end{tabular}


JES, Assiut University, Faculty of Engineering, Vol. 45, No. 6, November 2017, pp.773-790

\begin{tabular}{|c|c|c|c|c|c|}
\hline Authors & $\begin{array}{c}\text { Major } \\
\text { Findings }\end{array}$ & & & & \\
\hline & $\begin{array}{c}\text { RM } \\
\text { Definition } \\
\text { (RM is } \\
\text { about } \\
\text { anticipation } \\
\text { and } \\
\text { prevention) }\end{array}$ & $\begin{array}{c}\text { Classification of } \\
\text { Types of Risk } \\
\text { (Positive/negative, } \\
\text { Internal External, } \\
\text { Pure /Speculative, } \\
\text { Natural/human) }\end{array}$ & $\begin{array}{c}\text { Defining RM } \\
\text { process } \\
\text { (Identification, } \\
\text { analysis, } \\
\text { response } \\
\text { development, } \\
\text { control) }\end{array}$ & $\begin{array}{c}\text { RM } \\
\text { limitations } \\
\text { Worldwide }\end{array}$ & $\begin{array}{c}\mathrm{RM} \\
\text { limitations } \\
\text { in Egypt }\end{array}$ \\
\hline $\begin{array}{l}\text { Ben Horim \& } \\
\text { Levy, } 1980\end{array}$ & & $*$ & & & \\
\hline $\begin{array}{l}\text { Edward s \& } \\
\text { Bowen, } 1998\end{array}$ & & $*$ & & & \\
\hline Othman, 2010 & & $*$ & $*$ & & \\
\hline Piersonetal, 2011 & & $*$ & & & \\
\hline $\begin{array}{l}\text { Hammad et al, } \\
2012\end{array}$ & & & $*$ & & \\
\hline PMI, 2013 & & & $*$ & & \\
\hline $\begin{array}{ll}\text { Zavadskas } & \text { et } \\
\text { al, 2010 }\end{array}$ & & & $*$ & & \\
\hline $\begin{array}{l}\text { Akintoye \& } \\
\text { MacLeod, 1997 }\end{array}$ & & & & $*$ & \\
\hline $\begin{array}{lr}\text { Batlin } \quad \& \\
\text { Schacter, } 2000 \\
\end{array}$ & & & & $*$ & \\
\hline Hillson 2001 & & & & $*$ & \\
\hline Hillson 2006 & & & & $*$ & \\
\hline Taroun etal, 2011 & & & & $*$ & \\
\hline Zou et al, 2015 & & & & $*$ & \\
\hline $\begin{array}{l}\text { Khodeir L., et } \\
\text { al, } 2015\end{array}$ & & & & & $*$ \\
\hline $\begin{array}{l}\text { Sharaf \& } \\
\text { Abdelwahab , } \\
2015\end{array}$ & & & & & $*$ \\
\hline
\end{tabular}

\section{Methodology}

In order to achieve the objective of this paper, the author applied two main approaches: firstly, a literature review; secondly, an analysis of pilot case study of the Grand Egyptian Museum (GEM), where the latter included the application of one-to-one interview, Delphi technique and, finally, a questionnaire survey. Figure 3 shows the applied research methods and the objectives of their application.
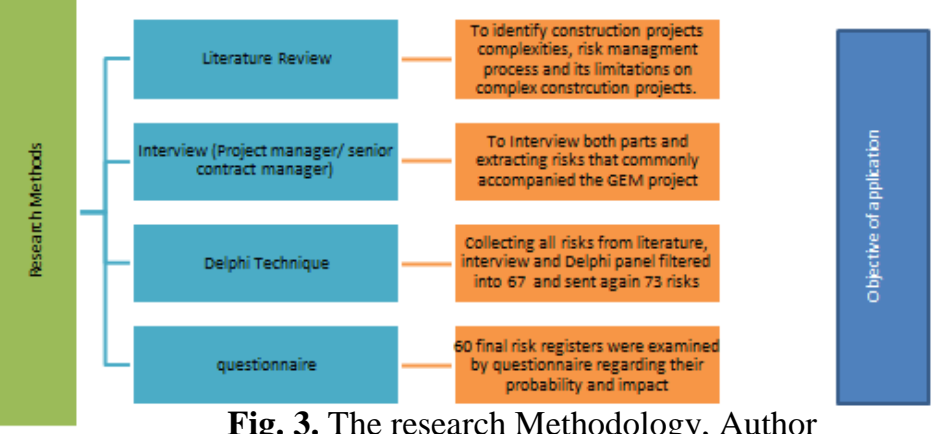

Fig. 3. The research Methodology, Author 


\subsection{One-to-One interview}

Two interviews were held by the author during the period of study (2014-2016). The objective of both was to extract the root causes and effects of risk in the complex GEM construction project. The first Interview was done with a former Project manager of the project in the beginning of 2015, whereas the other interview was done with a senior contracting manager in January 2016. Both Interviewees refused to include their names so the research is referring to them as anonymous 1, 2015 and anonymous 2, 2016. Each interview lasted for 2-3 hours. Table 4 shows the main objectives of both interviews.

\section{Table 4.}

Objectives of the one-to-one interview, Author

\begin{tabular}{|l|}
\hline Objectives /measured attributes \\
\hline $\begin{array}{l}\text { To identify the key risks affecting the complex GEM project along its life cycle (including pre- } \\
\text { contracting, contracting and construction until the end of the study) }\end{array}$ \\
\hline To determine the root causes of each type of identified risks and its relation to the project complexity. \\
\hline To identify the current practices (during the period of the study) to respond to risk. \\
\hline To highlight deficiencies or poor risk management practices. \\
\hline To design a realistic preliminary risk register of the GEM project. \\
\hline
\end{tabular}

\subsection{Delphi technique}

The Delphi panel consisted of 16 participants, including the interviewee. In the first round, a preliminary risk register was prepared based on the findings of the interviewee. This included 60 risks, and this register was then passed to other participants. A secondary risk register was thus produced including 73 different risks. After gathering the risks and refining them, 67 risks were finally produced. The refined risk register was resent to participants in the second round for further editing and commenting. Finally, a risk register of 60 risks was ready for further testing for probability and impact via survey questionnaire. Figure 4 shows the sample participants in the Delphi panels in terms of country of origin, and figure 5 highlights the percentage of participating groups. The age groups that shared in the Delphi panel were mostly experts with more than 30 years of working experience ( $40 \%$ of respondents).


Fig. 5. Percentage of participating group, author

\subsection{Questionnaire survey}

A questionnaire survey was finally conducted in order to measure both impact and probability of risks that were previously defined through the Delphi panel. In this survey, a purposeful sampling method was applied, in order to allow the researcher to pick the contributors according to their own specification. This type of sampling method was chosen as the participants were selected to be representatives of the entire population (i.e. architectural design organizations in Egypt). The architecture design organizations in Egypt that were already registered at the time of this research were forty four, according to 
the Egyptian Syndicate, thus a sample of 40 participants was applied to achieve an acceptable confidence level. Figure 6 shows the percentages of participants. Figures 6 and 7 respectively show the attributes of the respondents' main profile.

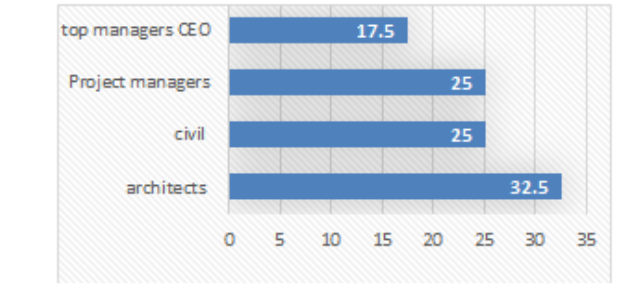

Fig. 6. the percentages of the participnts in the survey questiomaire, author

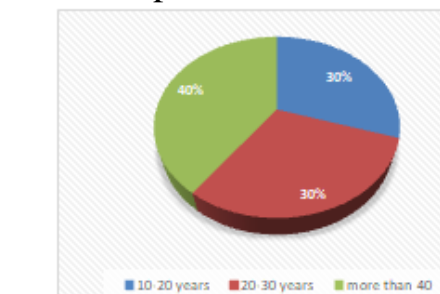

Fig. 7. years of experince of paticipants in questicmaire, athor

\section{Analysis of pilot case study: the grand Egyptian museum}

The Grand Egyptian Museum Project was inaugurated by the former Egyptian President, Hosni Mubarak, on Feb. $4^{\text {th }}, 2002$. It is Egypt's largest Cultural and iconic Project. It is intended to display the world's largest collection of Pharaonic Artifacts representing the evolution and ingenuity of the Ancient Egyptian civilization. The GEM is located at the outskirts of the ancient culture plateau of the Pyramids. It is designed on a gentle slope with a view to the Pyramids as well as a view towards the city of Cairo. The area of the project is about 493,579 $\mathrm{m}^{2}$ and occupies a total of 181,438 $\mathrm{m}^{2}$ in built up area, [26]. It is characterized by a $50 \mathrm{~m}$ level difference, created as the Nile passes through the desert to the Mediterranean, a geological condition that has shaped Egypt for over 3,000 years. The pyramids, funerary monuments, are located in the desert on the plateau $2 \mathrm{~km}$ from the museum site, while the site of the museum is located both in the valley and on the plateau. The design of the museum utilizes the level difference to construct a new 'edge' to the plateau, a surface defined by a veil of translucent stone that transforms from day to night. The museum exists between the level of the Nile Valley and the plateau, never extending above the plateau. The museum is envisaged as a cultural complex of activities devoted to Egyptology and contains $24,000 \mathrm{~m}^{2}$ of permanent exhibition space, almost 4 football fields in size, a children's museum, conference and education facilities, a large conservation center and extensive gardens on the 50 hectares site. Feasibility studies of the project estimate the number of visitors to the museum and the Giza pyramids as 5 millions every year. In 2020, the number of museum visitors is expected to rise to 8 millions, which will create demand for hotels, recreational parks and cultural centers, [28].

\subsection{Timeline of the GEM}

In 2002 the Head of Architecture department of Ain Shams University was assigned by the Ministry of Antiques and Ministry of Culture to form a committee for selecting a design for the newly proposed project of building a new Egyptian museum: a museum that will be a new iconic destination for displaying ancient Egypt's historic eras and artifacts. The idea of creating a new Egyptian museum was extremely welcomed and supported by the UNESCO. A competition was formed later on in 2002 to select the best possible design for the proposed project. A total of 2300 entries were made, 700 of which were then eliminated and 1600 were left. Out of the remaining participants, 20 designs were selected for the final rounds. A jury was formed of both Egyptian architects and members of international architectural community to select the top 3 designs. The First Prize was the Construction of the design and $250,000 \$$ [29]. In 2003, a preliminary project plan was offered, including the entire project's scope, from schematic design to project completion. A three-phased plan for project design 
Khodeir, Laila Mohamed, Efficient risk management: cause and effect analysis of key

and execution was proposed and an initial budget of 550 Million Dollars was projected. [30]. Figure 8 shows the estimated timeline for the project.



Fig. 8. Estimated timeline for the GEM, Author after [29], [30]

In 2005 the project scope rose from 550 to 800 million\$. This was due to project scale and complexity, where a number of buildings which were not intended in the original project were added. Additionally, there were complexities in transporting some monuments and antiques to the location of the museum. Funds were collected from various cultural philanthropists, (Anonymous, 2015). In 2009 the design documentation was delivered and initial site excavation began. The year 2011 had great impact on the project's performance due to the unrest in Egypt as a side effect of the revolution that took place, which gradually returned back to normal in 2012. In April, 2015, The Committee announced that further 300 million\$ were required to complete the project, which increased the overall projects' budget to 1.1 Billion\$ [29]. Table (5) shows both planned and actual timeline for the GEM. It is worth mentioning that starting from September 2015, slowdown of construction took place due to lack of finance. The case in the construction of the GEM is the completion of $70 \%$ and partial completion of MEP [32]. Figure 9 shows the actual timeline for the project implementation till the date of the research.

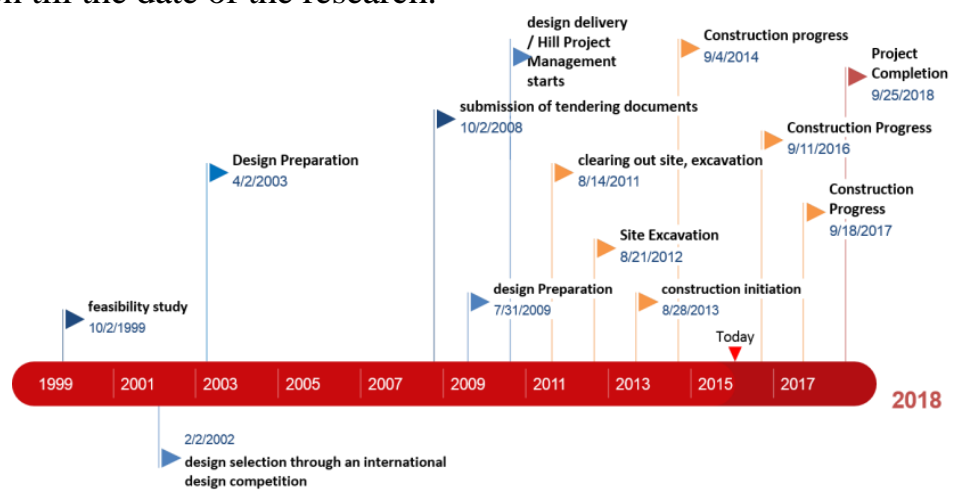

Fig. 9. Actual timeline for the GEM, Author

Table 5.

Actual and planned completion rates of the GEM project

\begin{tabular}{|l|l|l|l|l|}
\hline Year & Planned Phase Completion & $\begin{array}{l}\text { (Planned)\% } \\
\text { Completed }\end{array}$ & Actual Phase Completion & $\begin{array}{c}\text { (Real) \% } \\
\text { Completed }\end{array}$ \\
\hline 2002 & Design selection & 10 & Design selection & 10 \\
\hline 2003 & Design Preparation & 20 & Design Preparation & 20 \\
\hline 2004 & Design Preparation & 30 & Design Preparation & 20 \\
\hline 2005 & Design Delivery & 35 & Design Preparation & 20 \\
\hline
\end{tabular}


JES, Assiut University, Faculty of Engineering, Vol. 45, No. 6, November 2017, pp.773-790

\begin{tabular}{|l|l|l|l|l|}
\hline Year & Planned Phase Completion & $\begin{array}{l}\text { (Planned)\% } \\
\text { Completed }\end{array}$ & Actual Phase Completion & $\begin{array}{c}\text { (Real) \% } \\
\text { Completed }\end{array}$ \\
\hline 2006 & Site Excavation & 40 & Design Preparation & 20 \\
\hline 2007 & Site Excavation & 50 & Design Preparation & 20 \\
\hline 2008 & Construction Initiation & 60 & Design Preparation & 20 \\
\hline 2009 & Construction Progress & 70 & Design Preparation & 30 \\
\hline 2010 & Construction Progress & 80 & Design Delivery & 40 \\
\hline 2011 & Construction Progress & 90 & Site Excavation & 45 \\
\hline 2012 & Project Completion & 100 & Site Excavation & 50 \\
\hline 2013 & & 100 & Construction Initiation & 60 \\
\hline 2014 & & 100 & Construction Progress & 70 \\
\hline 2015 & $\begin{array}{l}\text { New extension in project } \\
\text { completion }\end{array}$ & 100 & Construction Progress & 80 \\
\hline 2016 & & 100 & Construction Progress & 90 \\
\hline 2017 & $\begin{array}{l}\text { New extension for project } \\
\text { completion }\end{array}$ & 100 & Construction Progress & 95 \\
\hline 2018 & & 100 & Project Completion (Estimated) & 100 \\
\hline
\end{tabular}

\subsection{Budget of GEM}

Based on the economic analysis in the Feasibility Study, the project costs amounted to 550 million dollars. This budget was financed through the following sources [33]:

- 100 million US dollars: SCA Self-Financing from "The Museums and Archeological Projects Fund" reserved to cover the completion of Phase I \& Phase II of the Project.

- 300 million US dollars: Japanese JICA Soft Loan to cover Phase III that included financing a greater part of the building construction, exhibition and interior design, landscape and urban design, and the ICT component .

- 150 million US dollars: Fund-Raising Campaign was planned to finance artifacts conservation, transfer of collections, fit out, furniture, Capacity-Building programs, and GEM building operations for one year after opening. Figure 10 shows the breakdown of the project budget.

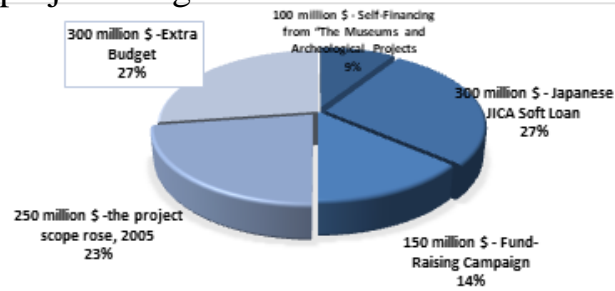

Fig. 10. G.E.M project's Budget Chart

4.3. Findings of risk identification through one-to-one interview (preliminary identification of risk)

The following table summarizes the basic types of risks that occurred throughout the life cycle of the GEM project in the period of that study (2014-2016). These risks were identified based on the interviews that were done and referred to earlier. Identified risks were categorized in relation to the project phase starting from site selection and ending up with anticipated risks in operation and maintenance phase. In addition, the types of project complexities which represent the root cause of risks were also discussed. Both the 
Khodeir, Laila Mohamed, Efficient risk management: cause and effect analysis of key

classification of risk and the type of complexities were identified and analyzed based on the findings of the literature review, Table 6.

Table 6.

Identified risks in the GEM, author after [29], [32]

\begin{tabular}{|c|c|c|c|}
\hline Project Phase & Project complexity & Negative risks (External /Internal) & Positive risks \\
\hline $\begin{array}{l}\text { a. Site selection: } \\
\text { Photo l. GEM site: [28] }\end{array}$ & 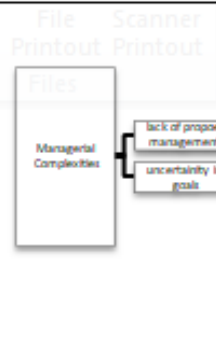 & $\begin{array}{l}\text {-Negative risk lies in the choice of building site location } \\
\text { beside a military unit, in the middle of slum areas. } \\
\text { (Internal Risk), Photol } \\
\text {-The site has no attractions, hotels, accommodations. } \\
\text { (External Risk) } \\
\text {-All surrounding land of the project's site is either owned } \\
\text { by the Army, Presidential Secret service or National } \\
\text { intelligence services. (External Risk) } \\
\text {-Due to political fears, no relocation of those institutes is } \\
\text { set to happen up until now. (Military sniper school is } \\
\text { intersecting the view of the pyramid from the GEM). } \\
\text { (External Risk) }\end{array}$ & $\begin{array}{l}\text {-The positive risk } \\
\text { lies is in the } \\
\text { opportunity the } \\
\text { building brings in } \\
\text { developing the } \\
\text { surrounding area, } \\
\text { the addition of } \\
\text { underground line } \\
\text { to the site and the } \\
\text { nearness of the } \\
\text { pyramid site (2 } \\
\text { km away) }\end{array}$ \\
\hline b. Contracting and tendering & 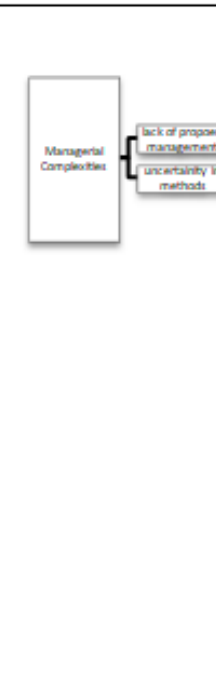 & $\begin{array}{l}\text {-Legislative risks in dealing with design competitions } \\
\text { (External Risk): } \\
\text { Law } 89 \text {-1998 for Bids and Auctions does not consider } \\
\text { design competitions as a legit bid or tender which is the } \\
\text { only allowed form of contracting (Government } \\
\text { contract). } \\
\text {-Lack of Project Manager in the applied methods of } \\
\text { contracting (Internal Risk): The contract signed } \\
\text { between the client (Government) and the project } \\
\text { management firm (Hill Int.) stated that the client must } \\
\text { provide the needed equipment for the work space ( } 50 \\
\text { Employees). The client was not able to fulfill that, due } \\
\text { to difficulties in providing specified specs, so the client } \\
\text { referred the director to the National Projects Services } \\
\text { of The Armed Forces (NPSAF). The NPSAF asked for } \\
3 x \text { (0.5 Million LE to } 1.5 \text { Million LE) the price of } \\
\text { equipment, with a } 70 \% \text { payment in advance, the } \\
\text { committee had to approve due to contract obligations } \\
\text { and timeline. } \\
\text {-Legislative Risks (External Risk): the absence of the } \\
\text { PM position recognition in Egyptian bylaws (Egyptian } \\
\text { law only recognizes and states the responsibilities for } \\
\text { consultants, clients \& contractors) }\end{array}$ & NA \\
\hline c. Project management &  & $\begin{array}{l}\text { - Project Finance and Decision making: (External Risk) } \\
\text { The role of the JICA (Japan International Cooperation } \\
\text { Agency) as the sponsor of the GEM with } 60 \% \text { of the } \\
\text { total budget as a soft loan forms negative risk on the } \\
\text { Egyptian employer regarding their authority and control } \\
\text { on decision making. } \\
\text {-Methods of finance: (Internal Risk) Assigning project } \\
\text { budget in Yen to avoid currency fluctuation and ensure } \\
\text { fair conditions, which was a success giving currency } \\
\text { shift, YEN vs USD, formed a negative risk from the } \\
\text { perception of contractor. } \\
\text {-Improper planning (External Risk): Project management } \\
\text { bid was created, won and dismissed three times due to } \\
\text { bad planning, missing documents, hesitation on behalf of } \\
\text { the client and mismanagement. } \\
\text { - Lack of proper decision making (Internal Risk): The } \\
\text { designer of the project did not proceed with it. The } \\
\text { contractor (Basix \& Oraskon joint venture) had to work } \\
\text { on producing working drawings of the project away from } \\
\text { the original designer and the HillEhaf joint venture } \\
\text { should approve the produced shop drawing. }\end{array}$ & $\begin{array}{l}\text {-Assigning } \\
\text { project budget in } \\
\text { Yen formed a } \\
\text { positive risk from } \\
\text { the perception of } \\
\text { owner. }\end{array}$ \\
\hline
\end{tabular}


Table 6. (Continue)

\begin{tabular}{|c|c|c|c|}
\hline d. Design Related & Toctinich & 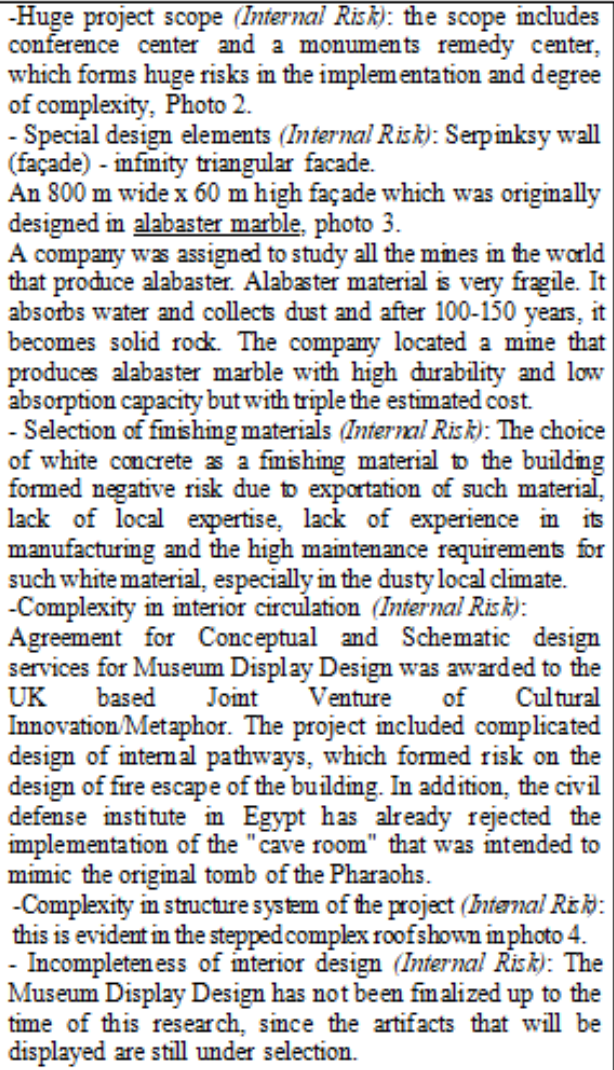 & \\
\hline $\begin{array}{l}\text { Photo 5. Ramses II statue } \\
\text { in the GEM site, author }\end{array}$ & $\left\{\begin{array}{l}\text { inign } \\
\text { wemsuction }\end{array}\right.$ & $\begin{array}{l}\text {-Multinational communication : Internal Risk } \\
\text { The project included multiple stakeholders with different } \\
\text { nationalities either in management, design, contracting, } \\
\text { finance and contractors. Joint ventures were made to } \\
\text { insure cooperation between Egyptian and non-Egyptian } \\
\text { stakeholders. For instance, Management \& Operations } \\
\text { Consultants included a joint venture between Hill } \\
\text { International from united states, Ehaf from Egypt and } \\
\text { Yamashita Sekki from Japan. The Construction } \\
\text { Contractors included Besix from Belgium and Orascom } \\
\text { Egyptian Constructions. } \\
\text { The consultants had to work on producing working } \\
\text { drawings of the project away from the original designer, } \\
\text { and the Hill/Ehaf joint venture should approve the } \\
\text { produced shop drawing. } \\
\text { Risks related to multicultural communication included } \\
\text { language and communication problems as well. } \\
\text {-Type of contracting (Internal Risk): the project in its } \\
\text { construction phase relied on international FEDEK pink } \\
\text { book contracts. This brought up risks related to the } \\
\text { difference in culture, where most Egyptian practitioners } \\
\text { were not used to documentation and preferred verbal } \\
\text { communication instead. }\end{array}$ & $\begin{array}{l}\text { - Multinational } \\
\text { communication: } \\
\text { The positive risk } \\
\text { lies in the } \\
\text { collaboration } \\
\text { between both local } \\
\text { culture (specified } \\
\text { with high } \\
\text { technicalities) and } \\
\text { international } \\
\text { cultures, specified } \\
\text { in management } \\
\text { practices. } \\
\text { This leads to } \\
\text { building a robust } \\
\text { system for } \\
\text { managing such } \\
\text { projects. }\end{array}$ \\
\hline
\end{tabular}


Table 6. (Continue)

\begin{tabular}{|c|c|c|c|}
\hline $\begin{array}{l}\text { Photo } 6: \text { S taillito wall } \\
\text { author }\end{array}$ & & $\begin{array}{l}\text { Communication between contractors and sub- } \\
\text { contractors, Local subcontractors had to practice writing } \\
\text { technical claims (in English) in order to resolve conflicts } \\
\text { that arose during construction phase. } \\
\text {-Authorization and decision making (Internal Risk): The } \\
\text { authorization was in the hand of HILL Ehaf Joint } \\
\text { venture, thus satisfying both partners was vital. This led } \\
\text { to complication in both decision making strategies and in } \\
\text { time consuming to reach decisions. } \\
\text {-Lack of finance (Internal Risk): due to lack of current } \\
\text { flows, the Egyptian finance has stopped FOR SOME } \\
\text { TIME, while the JICA was still funding the project in } \\
\text { Yen. This formed negative risk, as the value of yen has } \\
\text { dropped down relative to the value of the dollar, while } \\
\text { most finance and suppliers were paid in dollars, } \\
\text { especially MEP who supplies special type of glass. } \\
\text { Regarding local suppliers, they were affected by the } \\
\text { cutting of Egyptian government finance, as they were } \\
\text { paid in Egyptian pounds. } \\
\text {-Inaccurate determination of dependencies among } \\
\text { project phases (Internal Risk): } \\
\text { This risk aroused during the construction of building, } \\
\text { concurrently with transferring monuments in-site. } \\
\text { This formed negative risk on the great statue of Ramsis } \\
\text { II, which has been moved in-site, and was subjected to } \\
\text { in-site vibrations, photo } 5 \text {. } \\
\text { Complexity of structure: The staillito wall, photo } 6 \text {, is an } \\
\text { innovative structure system capable of bearing vertical } \\
\text { loads and, after finishing, will be very useful in enhancing } \\
\text { light reflections. The voids in that wall will be used to } \\
\text { install the HVAC ducts to air condition the higher levels } \\
\text { of the open space. However, the constructing team faced a } \\
\text { lot of issues in its execution owing to the complexity of it. }\end{array}$ & $\begin{array}{l}\text {-Type of } \\
\text { contracting: The } \\
\text { use of FIDIC: } \\
\text { with the contractor } \\
\text { joint venture basix } \\
\text { orascom, } \\
\text { contract had a } \\
\text { positive impact on } \\
\text { finding a common } \\
\text { language among } \\
\text { different } \\
\text { stakeholders from } \\
\text { different cultures } \\
\text { and countries. } \\
\text { FIDIC contract } \\
\text { also allowed for } \\
\text { the delay of } \\
\text { payment, slow } \\
\text { down of } \\
\text { construction work } \\
\text { and re-measuring } \\
\text { of quantities and } \\
\text { costs. } \\
\text { So it allowed for } \\
\text { flexibility of } \\
\text { payments, } \\
\text { regarding the } \\
\text { contractor side, } \\
\text { and coping with } \\
\text { changes. } \\
\text { determination of } \\
\text { dependencies: The } \\
\text { action that was } \\
\text { taken to protect } \\
\text { the statue was to } \\
\text { support it with } \\
\text { steel structure all } \\
\text { around, and cover } \\
\text { it with fabrics. It is } \\
\text { allocated at the } \\
\text { comer of the site } \\
\text { to avoid } \\
\text { vibrations. }\end{array}$ \\
\hline $\begin{array}{l}\text { E Expected Risks During } \\
\text { operation andmaintenanoe phase }\end{array}$ & 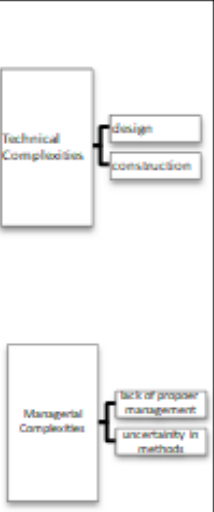 & $\begin{array}{l}\text { A number of negative risks that are related to both } \\
\text { technical and managerial complexities of the project are } \\
\text { anticipated as follows: } \\
\text { - Managerial complexities: Lack of facilities } \\
\text { management FMpartner. } \\
\text { - Technical complexities: this includes the choice of high } \\
\text { maintenance materials (white concrete), inaccessibility } \\
\text { for maintenance for the complicated design of roof, } \\
\text { where the stepped ceiling of the museum building is } \\
\text { covered with a horizontal mesh. Maintenance of roof } \\
\text { parts from inside will be hard and the mesh should be } \\
\text { operable in some parts to apply maintenance of building } \\
\text { systems. } \\
\text { This also forms a challenge in rain water drainage } \\
\text { systems. In addition, the project has a number of sloped } \\
\text { walls. These acute angles form risks and challenges to } \\
\text { the design of toilette units and for the maintenance of } \\
\text { such indoor acute angles. }\end{array}$ & \\
\hline
\end{tabular}

\subsection{Findings of Delphi panel and questionnaire survey (production of risk register)}

In the coming section of this paper, findings of both Delphi technique and questionnaire survey will be discussed. A sample of some of the identified negative risks from the risk 
register is shown in table 7, where all risks that were identified from interviews, were registered and sent to participants in the Delphi panel. Thus the objective of the Delphi technique was fulfilled.

Table 7.

Sample of the Risk Register for risks with negative impact

\begin{tabular}{|c|c|c|c|c|}
\hline \# & Risk description & $\begin{array}{l}\text { Type of } \\
\text { impact }\end{array}$ & $\begin{array}{l}\text { Type } \\
\text { of risk }\end{array}$ & $\begin{array}{c}\text { Type of } \\
\text { complexity (root } \\
\text { cause of risk) }\end{array}$ \\
\hline 1 & Site- related risks & Negative & & Managerial \\
\hline 2 & Legislative restrictions regarding competitions & Negative & & Managerial \\
\hline 4 & Lack of complex project management knowledge & Negative & & Managerial \\
\hline 5 & Lack of Client experience in complex Design projects & Negative & & Managerial \\
\hline 6 & Inefficient contracting methods & Negative & & Managerial \\
\hline 7 & $\begin{array}{l}\text { Design delivery delay due to misconduct in } \\
\text { contracting }\end{array}$ & Negative & & Managerial \\
\hline 8 & Increases of Design cost & Negative & & Managerial \\
\hline 10 & $\begin{array}{l}\text { Delay in construction due to design delay } \\
\text { (Client) }\end{array}$ & Negative & & Managerial \\
\hline 11 & Delay in construction due to design delay (management) & Negative & & Managerial \\
\hline 12 & Lack of accuracy in contract duration estimation & Negative & & Managerial \\
\hline 13 & Delay in design delivery due to improper planning & Negative & & Managerial \\
\hline 14 & Bad communication (Client) & Negative & & Managerial \\
\hline 15 & Bad Communication (Management) & Negative & & Managerial \\
\hline 16 & Inappropriate project phasing & Negative & & Managerial \\
\hline 17 & Slow/Poor Decision Making & Negative & & Managerial \\
\hline 19 & Penalty payment & Negative & & Managerial \\
\hline 20 & Waste of funds (Management) & Negative & & Managerial \\
\hline 21 & $\begin{array}{l}\text { Egyptian law does not recognize the project } \\
\text { management profession (Government Contracts) }\end{array}$ & Negative & & Managerial \\
\hline 22 & Lack of flexibility (Client) & Negative & & Managerial \\
\hline 23 & Poor Contracting Knowledge & Negative & & Managerial \\
\hline 24 & Limiting international ventures & Negative & & Managerial \\
\hline 28 & $\begin{array}{l}\text { Limiting exposure to international innovations } \\
\text { (Design \& Construction) }\end{array}$ & Negative & & Technical \\
\hline 31 & Poor documentation & Negative & & Managerial \\
\hline 32 & Mistrust (Bidders) & Negative & & Managerial \\
\hline 36 & Funds Reallocation (Client) & Negative & & Managerial \\
\hline 40 & Arbitrary Payment Requirements & Negative & & Managerial \\
\hline 41 & Incompleteness of design & Negative & & Technical \\
\hline 42 & Design specification changes during construction phase & Negative & & Technical \\
\hline 43 & Construction completion delay & Negative & & Managerial \\
\hline 44 & Unresolved consultancy Conflicts & Negative & & Technical \\
\hline 45 & Unresolved Design Conflicts in Construction Phase & Negative & & Technical \\
\hline 48 & Poor pre-design studies & Negative & & Technical \\
\hline
\end{tabular}

Figures 11 and 12 respectively show the findings obtained from the applied survey questionnaire, where participants determined risk probability and impact of all risks identified previously in the risk register. The figure shows only the key risks that got the highest score in terms of probability of occurrence and impact on project. 


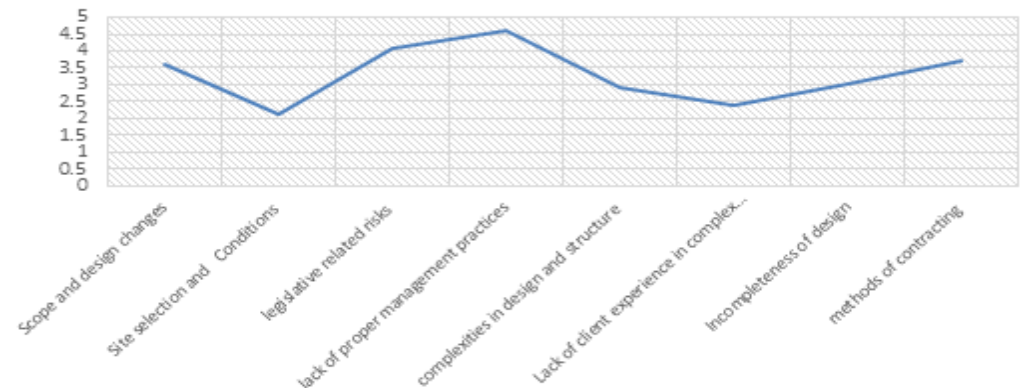

Fig. 11. Findings of Risk Probability, Author

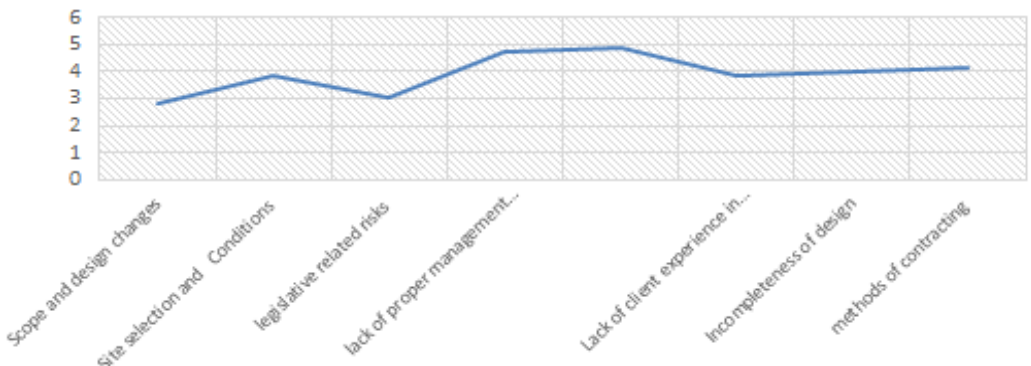

Fig. 12. Findings of Risk Impact, Author

\section{Conclusions}

The primary objective of this research was to undergo a cause and effect analysis of the key risks that face complex construction projects, thus enhancing their project delivery success. This aim was achieved primarily through the literature review, which provided knowledge for risk identification and analysis. In addition, the analysis of types of project complexities and their relation to anticipated types of risks in the case study of the GEM was based upon the findings of the literature.

Afterwards, the case of the GEM was taken as a pilot case study for a typical complex construction project. The study was limited to the time period between 2014 and 2016, since the project is ongoing and still in progress. Through the analysis of the case study, a number of risks and their root causes in relevance to the project complexities have been identified. However, to make full benefit of the primary results that were based on interviewing stakeholders, the results were then disseminated and refined through Delphi panel. Finally, the questionnaire survey widened the perspective of the results of the study and made them applicable to other complex projects other than the GEM.

According to the paper findings, the top identified risk and their root causes are as follows:

a. Risks related to complexities in design and structure: these risks were found to have the greatest impact on complex projects, were the design of complex structure systems, innovative design elements, sloped and inclined surfaces severely affected the case in hand completion date and budget. Such complexities also have a negative impact on the buildings during operation and maintenance phase.

b. Lack of proper management practices, which was evident in the GEM project in the project planning, inaccurate determination of project dependencies, scope creep, decision making, cost management and stakeholders' management. The root causes of such risks lie in uncertainty in management methods and goals. This type of risk was found to be the first in its probability of occurrence and almost shares the first place with design complexities as the most impacting type of risks in complex construction projects. 
c. Legislative-related risks were found to be the second most probable risks. These risks include all issues related to the Egyptian law of auctions and bidding, law 98 which organized the tendering and bidding in the form of technical and financial committees. This allows nonprofessional organizations to win the bids, even if not qualified, just because they offered a low bid. Not considering design competitions as a method of bidding urged to divide the contract into pieces and at the end the design firm quitted the project. This risk is considered external and is again related to managerial complexities, particularly to uncertainties in methods.

d. Scope and design changes and methods of contracting represented the third most probable type of risks. Although both risks are related to managerial complexities, namely uncertainties in management methods and goals, changes in design and scope are also related to technical complexities including scope, design and construction complexities.

Regarding the Egyptian context and the top occurring risks in complex projects, findings of this paper show that a number of corrective actions should be adopted, including:

- Review and modification of law 89-1998, which represents a major setback for future Multinational collaborative projects, as it limits the competitiveness of quality and emphasis of quantity.

- Complex Construction projects need special consideration in terms of bidding and tendering as the selection process should be based mainly on quality of provided work.

The main contribution of this study to the body of knowledge in the field of risk management wasn't only documenting lessons learned from a case study of a complex construction project, but also offering a cause effect analysis that could be highly beneficial to both project managers and stakeholders of such projects, either in Egypt or in other similar construction cultures.

\section{Limitations}

This study took place in the period between December 2014 and January 2016. Although the author of this paper used several procedures to broaden the application of the results, the results provided are still restricted and need to be verified by being applied on the GEM building along its life time. It is recommended to perform quantitative risk analysis at the completion of the project in order to prove the results of this study.

\section{REFERENCES}

[1] Sharaf, M. M., \& Abdelwahab, H. T. (2015). Analysis of Risk Factors for Highway Construction Projects in Egypt. Journal of Civil Engineering and Architecture, 9 (12), 526-533.

[2] Patrick X.W. Zou, Guomin Zhang, Jiayuan Wang, (2007). Understanding the key risks in construction projects in China - International Journal of Project Management. 25, 601-614.

[3] He Zhi, (1995), Risk management for overseas construction projects, International Journal of Project Management. Vol. 13, No. 4, pp. 231-237.

[4] Khodeir, L. M., \& Mohamed, A. H. (2015). Identifying the Latest Risk Probabilities Affecting Construction Projects in Egypt According to Political and Economic Variables. From January 2011 to January 2013. HBRC Journal, 11 (1), 129-135.

[5] Dictionary (2006). Collins English Dictionary and Thesaurus. Glasgow: Harper Collins.

[6] Williams, C. A., Smith, M. L., \& Young, P. C. (1995). Risk management and insurance (7th Edition ed.). New York City, New York, United States of America: Mcgraw-Hill College.

[7] Baccarini, D. (1996). The concept of project complexity - a review. International Journal of Construction Management. 14: 201-204. 
Khodeir, Laila Mohamed, Efficient risk management: cause and effect analysis of key

[8] Mills, A. (2001) A systematic approach to risk management for construction. Structural survey. 19: 254-252.

[9] Mulholland, B. \& Christian, J. (1999) Risk assessment in construction schedules. Journal of Construction Management. JAN/FEB 99: 8-15.

[10] Gidado, K. (2004) Enhancing the prime contractors pre-construction planning. Journal of Construction Research. 5: 87-106

[11] Bertelsen, S. (2003) Complexity - construction in a new perspective. $11^{\text {th }}$ Annual conference in the international group for lean construction. Blacksburg, VA.

[12] Chapman R.J., (2001), "The Controlling Influences on Effective Risk Identification and Assessment for Construction Design Management”, Internat. J. of Project Manag., Vol. 19, pp. 147-160.

[13] Shen L.Y., Wu G.W.C., Ng C.S.K., (2001), "Risk Assessment for Construction Joint Ventures in China. J. of Constr. Eng. and Manag., Vol. 127, No.1, pp.76-81.

[14] Chen H., Hao G., Poon S.W., Ng F.F., (2004), "Cost Risk Management in West Rail Project of Hong Kong", AACE Internat. Trans.

[15] Dikmen I., Birgonul M., Han S., (2007), "Using Fuzzy Risk Assessment to Rate Cost Overrun Risk in International Construction Projects”, Internat. J. of Project Manag., Vol. 25, pp. 494-505.

[16] Zeng J., An M., Smith N.J., (2007), “Application of a Fuzzy Based Decision Making Methodology to Construction Project Risk Assessment”, Internat. J. of Project Manag., Vol. 25, pp. 589-600.

[17] Matineh Eybpoosh, Irem Dikmen, and M. Talat Birgonul, (2011), "Identification of Risk Paths in International Construction Projects using Structural Equation Modeling", ASCE Journal of Construction Engineering and Management, Vol. 137, No. 12, pp. 1164-1175, December.

[18] Othman, A. A. (2010). Value and risk management for dynamic brief development in construction. Lambert Academic Publishing.

[19] Ben-Horim, M., \& Levy, H. (1980). Total Risk, Diversifiable Risk and Non-diversifiable Risk: A Pedagogic Note. The Journal of Financial and Quantitative Analysis, 15 (2), 289-297.

[20] Peirson, G., Brown, R., Easton, S., Howard, P., \& Pinder, S. (2011). Business Finance (11th Edition ed.). McGraw-Hill Australia.

[21] Duncan, W. R. (1996). A guide to the project management body of knowledge (PMBOK Guide). Newton Square, Pa, USA: Project Management Institute, Inc.

[22]Zavadskas, E. K., Turskis, Z., \& Tamošaitien, J. (2010). Risk Assessment of Construction Projects. Journal of Civil Engineering and Management , 16 (1), 33-46.

[23] Goral, J. (2007). Risk Management in the Conceptual Design Phase of Building Projects. CHAMLERS University Structural engineering joural, pp.17-35.

[24] Hillson, D. (2006). Integrated Risk Management as a Framework for Organizational Success. PMI Global Congress Proceedings. Seattle: Project Management Institute.

[25] Akintoye, A. S., \& MacLeod, M. J. (1997). Risk Analysis and Management in Construction. International Journal of Project Management, 15 (1), 31-38.

[26] Zou, Y., Kiviniemi, A., \& Jones, S. W. (2015). BIM-based risk management: challenges and opportunities. Proceedings of the $32^{\text {nd }}$ CIB W78 Conference 2015. Eindhoven.

[27] Taroun, A., Yang, J., \& Lowe, D. (2011). Construction Risk Modelling and Assessment: Insights from a Literature Review. The Built \& Human Environment Review, 4 (1), 87-97.

[28] MOC, (2010). Ministry of Culture - The Grand Egyptian Museum -Project Implementation Report.

[29] Anonymous 1, (2015). Former Manager of GEM, Interview, Cairo, Egypt.

[30] MOA, (2015). Ministry of Antiques. The Grand Egyption Museum Website. http://www.gem.gov.eg/.last accessed 1/11/2015.

[31] Ayad, M., (2015), $300 \mathrm{~m}$ needed to complete Grand Egyptian Museum: Antiquities Ministry. Daily News Egypt, http://www.dailynewsegypt.com/2015/04/26/300m-neededto-complete-grand-egyptian-museum-antiquities-ministry/.

[32] Anonymous 2, (2016). contractor manager at GEM, Interview, Cairo, Egypt.

[33] GEM, (2015). Official page of GEM, http://www.gem.gov.eg/index/Project Project\%20Funding.htm. Last updated April, 2015. 


\section{إدارة فعالة للمخاطر : تحليل مسببات وتوابع المخاطر المفتاحية

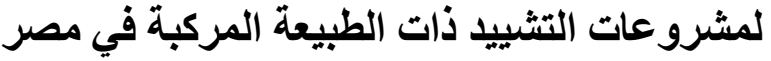

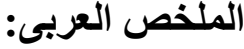

تتصف مشرو عات التشيبد، والتي تستهلك إطارًا زمنيًا محددًا، بكونها ذات طبيعة مركبة, حيث تحتوي

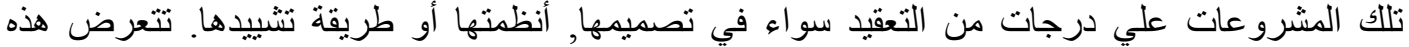

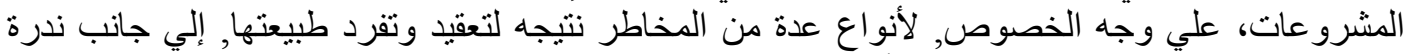

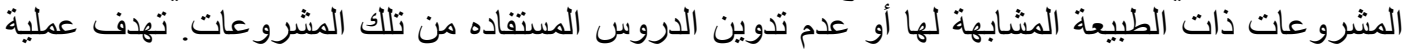

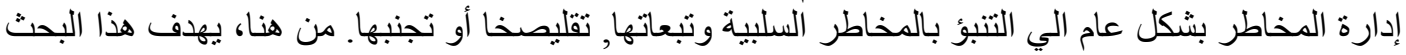

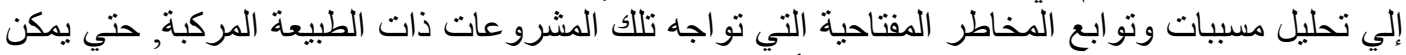

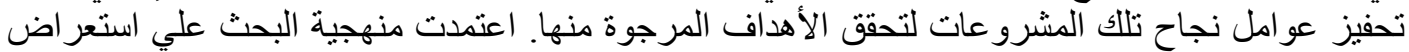

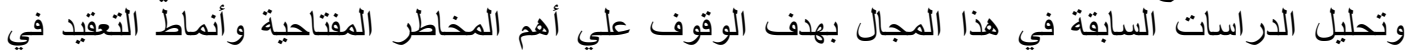

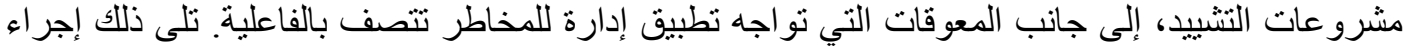

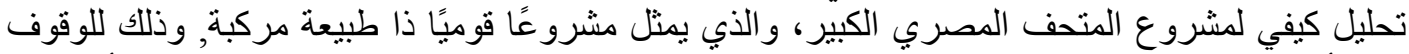

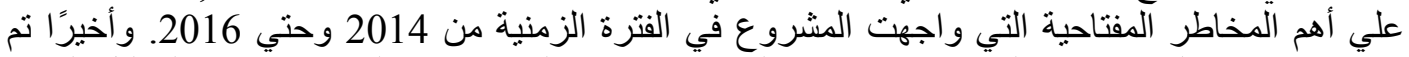

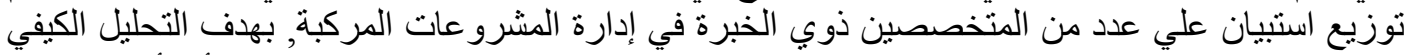

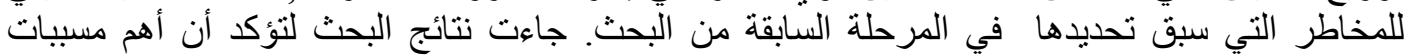

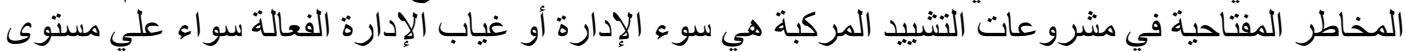

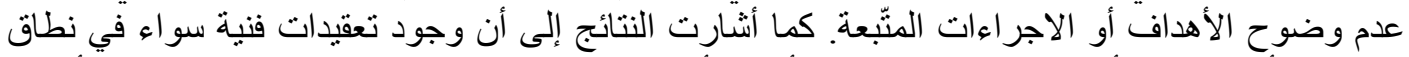

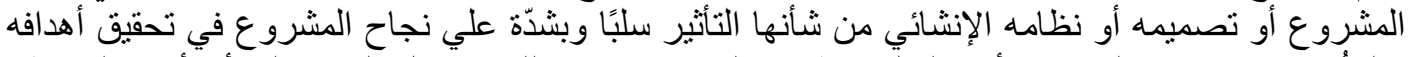

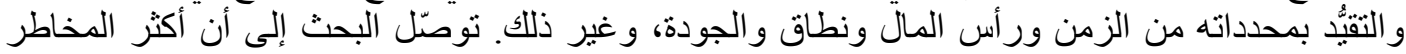

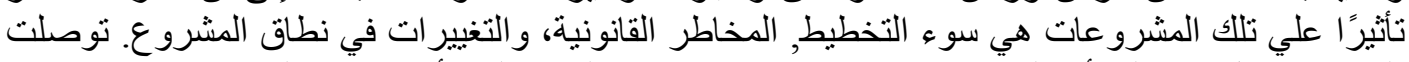

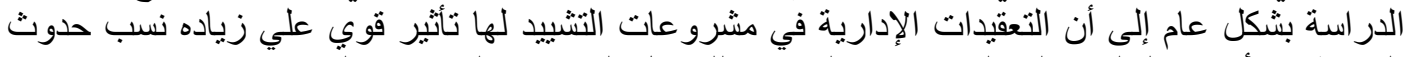



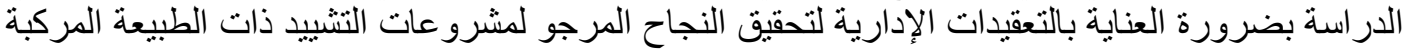

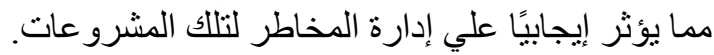

